\title{
Probable ATP-Dependent RNA Helicase DDX58
}

National Cancer Institute

\section{Source}

National Cancer Institute. Probable AT P-Dependent RNA Helicase DDX58. NCI

Thesaurus. Code C101421.

Probable ATP-dependent RNA helicase DDX58 (925 aa, 107 kDa) is encoded by the human DDX58 gene. This protein plays a role in the regulation of viral defense. 